Ana M. Stojanović

Università degli Studi di Bari

Dipartimento Lelia

marebluetranslations@gmail.com
UDK: 811.163.41: 811.131.1'255.4

DOI: 10.19090/ZJIK.2021.71-84

originalni naučni rad

\title{
INTERLINGVISTIČKO PREVOĐENJE METAFORA U IDIOMATSKIM IZRAZIMA SA ITALIJANSKOG NA SRPSKI JEZIK ${ }^{1}$
}

SAŽETAK: Naučnici i istraživači koji se bave semiotikom prevođenja složni su u zapažanjima da semioza nikada ne može biti prekinuta i da je, stoga, prevođenje uvek moguće. Međutim, i pored njihovih stavova, metafore ali i idiomatski izrazi koje one čine, a koje karakterišu svaki kulturni kontekst, jedan su od najvećih izazova kako za semiotičare tako i za prevodioce. U ovom radu našu pažnju ćemo posvetiti prevodu metafora u idiomatskim izrazima, ali i ambivalentnim metaforama i njihovom ispravnom prevodu. Cilj će svakako biti doprinos radu prevodioca u susretu sa ovakvim jezičkim elementima. Metodologija će se zasnivati na semiotičkoj analizi korpusa koji je sakupljen na osnovu dva kriterijuma: po prvom kriterijumu sakupljeni su oni izrazi koji se ne pominju u frazeološkim rečnicima i oni izrazi za koje rečnici ne beleže sve moguće prevode. Drugi kriterijum je formiran na osnovu same metafore u izrazu, koja je semantički morala biti potpuno drugačija u srpskom i italijanskom jeziku, ali ne i sintaktički (u smislu enuncijatuma²).

Ključne reči: metafore, idiomatski izrazi, ambivalentnost, italijanski, srpski

\section{UVOD}

Idiomatski izrazi, koji karakterišu svaki kulturni kontekst, jedan su od najvećih izazova za prevodioce. Oni ne predstavljaju samo skup metafora, semiotičkih znakova (dakle, i značenja), već na neuobičajen način izražavaju metaforički smisao izraza. Metafore su „semantička pomeranja pri kojima se u

\footnotetext{
1 Rad je prevod IV poglavlja doktorske disertacije pod nazivom Interpretazione $e$ traduzione interlinguistica: ai confini dell'intraducibile, pripremljene pod mentorstvom prof. Augusta Poncija (Augusto Ponzio) i Susan Petrili (Susan Petrilli) sa Univerziteta u Bariju, na smeru Semiotika prevođenja i filosofija jezika. Doktorska disertacija je odbranjena u maju 2017. god. na Univerzitetu u Bariju.

${ }^{2} \mathrm{U}$ lingvistici enuncijatum je iskaz sačinjen od znakova i zvukova koji dobijaju značenje u određenom kontekstu. U tom smislu se razlikuje od fraze (rečenice), koja je kao jedinica jezičkog sistema apstraktno shvaćena, ali koja, za razliku od enuncijatuma, ne mora zavisiti od konteksta.
} 
dodiru semantički heterogenih termina generiše semantički sudar“ (Cacciari 1991: 6). Prevesti taj „semantički sudar“ ponekad je izuzetno teško, naročito kada se susretnemo sa semantičkom međujezičkom nesaglasnošću. Činjenica da se ovakvi izrazi u dvojezičnim rečnicima (kada postoji njihov prevod) često objašnjavaju pomoću drugih rečenica ili nekih drugih idiomatskih izraza, predstavlja problem za prevodioce. Tek kada počnemo da ih analiziramo ili razmatramo $u$ sintaksičkom i leksičkom smislu, shvatamo da većini njih ne znamo ni etimologiju ni odgovarajući prevod. Da li semiotičko prepoznavanje znaka, analizom znakovnih elemenata, signifikanata i interpretanata, može rešiti teškoće $u$ prevođenju? Kada su u pitanju metafore iz idiomatskih izraza, zaista se čini da ne može, iako je po Persu u osnovi semiotičkog razmišljanja o prevođenju neprekidna semioza, te stoga on zastupa stav o uvek mogućem, odnosno ostvarivom prevodu (Peirce 2003).

Po čuvenom lingvisti Ferdinandu de Sosiru (Saussure 2009), vrednost znaka se krije u njegovoj sposobnosti da postoji kao deo većeg sistema. Ovako „strukturalističko“ razmišljanje nam omogućava da razumemo „tehniku zamene u prevodilačkom procesu“" po interesantnom kriterijumu koji su razvili Vine i Darbelne (u Mounin 2006: 65). Korišćenje ,pomoći“ pri prevođenju dokazuje da za semiotiku prevodilački proces nikad ne može biti nemoguć, jer ono što je bitno nije značenje već smisao.

Prvi problem je, svakako, prepoznavanje metafora. Nisu retki slučajevi kada prevodilac prevodi metafore, a samim tim i idiomatske izraze, kao rečenice bez posebnog, odnosno dodatnog značenja jer se one ponekad mogu činiti takvim, iako se na ovaj način gubi njihov metaforički smisao. Zaista je malo primera ovakvih izraza koji prevodiocima ne stvaraju poteškoće, što se može desiti ukoliko je reč o dve obično bliske kulture u kojima je idiomatski izraz zasnovan na istoj metafori.

\section{KORPUS}

U ovom radu korpus je sakupljen na osnovu dva kriterijuma: po prvom kriterijumu sakupljeni su oni izrazi koji se ne pominju u italijansko-srpskim frazeološkim rečnicima i oni koji, ukoliko se i pominju, kao što je slučaj u malobrojnim primerima koji slede, ne beleže sve moguće prevode. Drugi kriterijum je formiran na osnovu same metafore u izrazu, koja je semantički morala biti potpuno drugačija, ali, naravno, ne i sintaktički (u smislu enuncijatuma). Naime, prevodioci znaju da se njihov optimalni rad u ovakvoj vrsti 
prevoda (iako nije uvek moguć) sastoji u pronalaženju drugačije metafore, izgradnji drugog idiomatskog izraza, koji bi, međutim, izazvao isti efekat na nivou enuncijatuma. Problem je zasigurno izraženiji kod simultanih i konsekutivnih prevodilaca iz razumljivih razloga, stoga je nekad i opravdano izostaviti nepoznat frazelogizam, imajući u vidu da je, kako smatra Karlo Čipoli, „za simultanog prevodioca važno preneti poruku, dok je za ostale prevodioce važan način na koji

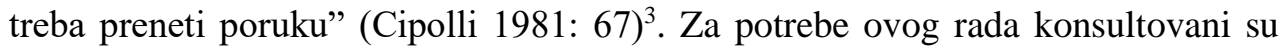
rečnici: Frazeološki srpsko-italijansko-francuski rečnik (Golović 2010), Italijansko-srpski rečnik (Klajn 2005), Srpske narodne izreke 1 (Stojičić 2006), kao i Zašto se kaže (Šipka 2010), Vocabolario della lingua italiana (Zingarelli 2004), Poslovice naroda sveta (Ristić 1992), Dizionario dei proverbi italiani e dialettali (Schwamenthal, Straniero 1999) i Dizionario dei modi di dire (Craici 2001). Našu pažnju ćemo posvetiti i ambivalentnim metaforama i njihovom ispravnom prevodu.

\section{ANALIZA KORPUSA}

Da bismo uspešno preveli metaforu i idiomatski izraz čiji je ona deo, nekada je važan i stilski i konotativni aspekt kao i sveukupni kontekst. Prevodilac neretko pojednostavljuje ovakve izraze, na primer tako što izostavi metaforu (u nastavku rada predstavićemo konkretne primere). Drugo rešenje je formiranje kalka, koji je najčešće neuobičajen za slušaoca ili čitaoca, ali koji omogućava prevodiocu da održi metaforu ili metaforički smisao izraza. Na taj način čitaoci će shvatiti pravo značenje, koje je ponekad lako razumljivo, ponekad zanimljivo, ponekad bizarno, ali ponekad u potpunosti nerazumljivo.

I srpski i italijanski jezik u svojim strukturama imaju idiomatske izraze koji su posledica bogatog jezičkog i kulturnog iskustva, ali i pokazatelj bogate filozofije života.

U nastavku će biti jasno prikazano koji frazeološki izraz ili predlog za prevod već postoji u rečnicima, a koji je naš predlog prevoda. Novost će svakako biti i etimološka objašnjenja frazeologizama, koja se ne pronalaze u rečnicima, kao i određen broj frazeologizama koji nisu zabeleženi u rečnicima, a za koja ćemo pokušati pronaći adekvatan prevod. Cilj će svakako biti doprinos radu prevodilaca oba jezika.

U prvoj koloni tabelarnog prikaza, izdvojili smo izraze iz italijanskog jezika. U drugoj koloni taj izraz je interpretiran na srpskom jeziku, a u trećoj

\footnotetext{
${ }^{3}$ Prevod autora rada.
} 
koloni je ponuđen prevod. Ukoliko pak idiomatski izraz ne postoji, praznina će biti označena crticom (-). Objašnjenje izraza biće napisano na srpskom jeziku. Razlika između idiomatskih izraza i poslovica nije strogo naglašena, stoga će se u određenom broju primera pojaviti i poslovice koje sadrže metaforu karakterističnu za idiomatske izraze jer one delom i jesu idiomatski izrazi ukorenjeni u narodnu tradiciju, koji pri tome sadrže moralnu ili didaktičku poruku. Po rečima Pitana, „one su veoma kratki sažeci elementarnih iskustava“"(Pittano 2009: 5).

\begin{tabular}{|c|c|c|}
\hline $\begin{array}{l}\text { Idiomatski izraz na } \\
\text { italijanskom jeziku: }\end{array}$ & $\begin{array}{l}\text { Doslovan prevod } \mathbf{i} \\
\text { interpretacija }\end{array}$ & Prevod \\
\hline gettare la spugna & $\begin{array}{l}\text { „Baciti sunđer“; nekada } \\
\text { je za vreme bokserskog } \\
\text { meča, trener bacao peškir } \\
\text { (u prošlosti sunđer) kako } \\
\text { bi sprečio loš ishod } \\
\text { samog meča, najavljujući } \\
\text { predaju svog takmičara. }\end{array}$ & $\begin{array}{l}\text { Idiomatski izraz na } \\
\text { srpskom jeziku: } \\
(-) \\
\text { Predlog za prevod: } \\
\begin{aligned} \text { 1. } & \text { Pustiti niz } \\
& \text { reku. } \\
\text { 2. } & \text { Predati se. }\end{aligned}\end{array}$ \\
\hline avere l'argento vivo addosso & $\begin{array}{l}\text { „Imati živo srebro/živu na } \\
\text { sebi“, biti živahan i } \\
\text { nemiran; empirijska } \\
\text { nauka nam pokazuje da } \\
\text { živa na površini ne može } \\
\text { biti mirna i da se čak i } \\
\text { kap žive izuzetno brzo } \\
\text { kreće, odatle i poreklo } \\
\text { izraza. }\end{array}$ & $\begin{array}{l}\text { Idiomatski izraz na } \\
\text { srpskom jeziku: Ponašati } \\
\text { se/ biti kao čigra. }\end{array}$ \\
\hline $\begin{array}{l}\text { chi ha buon marito lo porta in } \\
\text { viso } \\
\text { (proverbio) }\end{array}$ & $\begin{array}{l}\text { „Dobar muž se nosi na } \\
\text { licu.“ }\end{array}$ & $\begin{array}{l}\text { Idiomatski izraz na } \\
\text { srpskom jeziku: Žena } \\
\text { muža nosi na licu, a muž } \\
\text { ženu na košulji. }\end{array}$ \\
\hline $\begin{array}{l}\text { mogli e buoi dei paesi tuoi } \\
\text { (proverbio) }\end{array}$ & & $\begin{array}{l}\text { Idiomatski izraz na } \\
\text { srpskom jeziku: } \\
\text { Kravu i ženu iz istog sela } \\
\text { biraj. }\end{array}$ \\
\hline piovere sul bagnato & $\begin{array}{l}\text { „Kiša pada na mokro } \\
\text { tlo.“ }\end{array}$ & $\begin{array}{l}\text { Idiomatski izraz na } \\
\text { srpskom jeziku: Nesreća } \\
\text { nikad ne ide sama. }\end{array}$ \\
\hline ad ogni morte di Papa & $\begin{array}{l}\text { „Kad god papa umre“; } \\
\text { veoma retko. }\end{array}$ & $\begin{array}{l}\text { Idiomatski izraz na } \\
\text { srpskom jeziku: } \\
(-)\end{array}$ \\
\hline
\end{tabular}




\begin{tabular}{|c|c|c|}
\hline & & $\begin{array}{l}\text { Predlog za prevod: } \\
\text { Na Svetog Živka } \\
\text { (međutim, u ovom slučaju } \\
\text { značenje je „nikad“). }\end{array}$ \\
\hline al dente & $\begin{array}{l}\text { „Na zub“, predstavlja } \\
\text { način kuvanja testenine i } \\
\text { pirinča tako da se jelo ne } \\
\text { prekuva i ne bude previše } \\
\text { meko već čvrsto pod } \\
\text { zubima. }\end{array}$ & $\begin{array}{l}\text { Idiomatski izraz na } \\
\text { srpskom jeziku: } \\
\text { (-) izraz ne postoji zbog } \\
\text { različite kulinarske kulture } \\
\text { Predlog za prevod: } \\
\text { Do srednje čvrstoće. }\end{array}$ \\
\hline andare a naso & $\begin{array}{l}\text { Raditi nešto prateći } \\
\text { sopstvenu intuiciju }\end{array}$ & $\begin{array}{l}\text { Idiomatski izraz na } \\
\text { srpskom jeziku: } \\
\text { (-) } \\
\text { Predlog za prevod: } \\
\text { Po osećaju }\end{array}$ \\
\hline $\begin{array}{l}\text { arrampicarsi sui vetri/ sugli } \\
\text { specchi }\end{array}$ & $\begin{array}{l}\text { „Penjati se po } \\
\text { staklu/ogledalu“; } \\
\text { uzaludno pokušavati } \\
\text { argumentovano objasniti. }\end{array}$ & $\begin{array}{l}\text { Idiomatski izraz na } \\
\text { srpskom jeziku: } \\
\text { (-) } \\
\text { Predlog za prevod: } \\
\text { Pokušavati nemoguće. }\end{array}$ \\
\hline canto del cigno & $\begin{array}{l}\text { Po legendi, labud peva } \\
\text { samo jednom i to pred } \\
\text { svoju smrt. Izraz se } \\
\text { koristi kao znak poslednje } \\
\text { pobede pre poraza. U } \\
\text { srpskom jeziku se koristi } \\
\text { i za poslednju } \\
\text { manifestaciju nekakvog } \\
\text { talenta kao i za poslednji } \\
\text { nastup kojim se označava } \\
\text { kraj umetničke karijere. }\end{array}$ & $\begin{array}{l}\text { Idiomatski izraz na } \\
\text { srpskom jeziku: } \\
\text { Labudova pesma. }\end{array}$ \\
\hline dalla padella alla brace & „Iz tiganja u žar.“ & $\begin{array}{l}\text { Idiomatski izraz na } \\
\text { srpskom jeziku: } \\
\text { Od zla gore. }\end{array}$ \\
\hline dare i numeri & $\begin{array}{l}\text { „Ponuditi brojeve“; } \\
\text { govoriti stvari bez smisla. }\end{array}$ & $\begin{array}{l}\text { Idiomatski izraz na } \\
\text { srpskom jeziku: Lupati } \\
\text { kao maksim po diviziji. }\end{array}$ \\
\hline fare di tutta l'erba un fascio & $\begin{array}{l}\text { „Od sve trave praviti isti } \\
\text { svežanj“; generalizovati. }\end{array}$ & $\begin{array}{l}\text { Idiomatski izraz na } \\
\text { srpskom jeziku: } \\
\text { Stavljati sve u isti koš. }\end{array}$ \\
\hline
\end{tabular}




\begin{tabular}{|c|c|c|}
\hline fare il portoghese & $\begin{array}{l}\text { „praviti se Portugalac“; } \\
\text { ući krišom a ne platiti } \\
\text { kartu }\end{array}$ & $\begin{array}{l}\text { Idiomatski izraz na } \\
\text { srpskom jeziku: } \\
(-) \\
\text { Predlog za prevod: } \\
\text { Švercovati se. }\end{array}$ \\
\hline farina del mio sacco & $\begin{array}{l}\text { „Brašno iz mog džaka“; } \\
\text { lična misao, ideja. }\end{array}$ & $\begin{array}{l}\text { Idiomatski izraz na } \\
\text { srpskom jeziku: Mojih } \\
\text { ruku delo. }\end{array}$ \\
\hline farla sempre franca & $\begin{array}{l}\text { Izvući se bez štete ili } \\
\text { kazne. }\end{array}$ & $\begin{array}{l}\text { Idiomatski izraz na } \\
\text { srpskom jeziku: } \\
\text { Izvući se kao puvanjak. }\end{array}$ \\
\hline metterci una croce sopra & $\begin{array}{llr}\text { „Staviti } & \text { krst } & \text { preko } \\
\text { nečega“; } & \text { završiti } & \text { sa } \\
\text { nečim. } & & \\
\end{array}$ & $\begin{array}{l}\text { Idiomatski izraz na } \\
\text { srpskom jeziku: } \\
\text { Raskrstiti. }\end{array}$ \\
\hline $\begin{array}{l}\text { gatta morta (u okviru izraza } \\
\text { fare la gatta morta) }\end{array}$ & $\begin{array}{l}\text { „Mrtva mačka“; praviti se } \\
\text { naivan. }\end{array}$ & $\begin{array}{l}\text { Idiomatski izraz na } \\
\text { srpskom jeziku: } \\
\text { Biti kao francuska } \\
\text { sobarica. }\end{array}$ \\
\hline indorare la pillola & $\begin{array}{l}\text { „Pozlatiti pilulu“; } \\
\text { ulepšati stvari/stvarnost; } \\
\text { u prošlosti su farmaceuti } \\
\text { imali običaj da pozlaćuju } \\
\text { ili posrebljuju pilule kako } \\
\text { bi ih učinili manje } \\
\text { odbojnim. }\end{array}$ & $\begin{array}{l}\text { Idiomatski izraz na } \\
\text { srpskom jeziku: } \\
\text { (-) } \\
\text { Predlog za prevod: } \\
\text { Ulepšavati stvarnost. }\end{array}$ \\
\hline nelle braccia di Morfeo & $\begin{array}{l}\text { U Morfejevom zagrljaju; } \\
\text { Morfej je u grčkoj } \\
\text { mitologiji bog snova. }\end{array}$ & $\begin{array}{l}\text { Idiomatski izraz na } \\
\text { srpskom jeziku: } \\
(-) \\
\text { Predlog za prevod: } \\
\text { U svetu snova. }\end{array}$ \\
\hline Paganini non ripete & $\begin{array}{l}\text { „Paganini ne ponavlja“; } \\
\text { kada odbijamo da nešto } \\
\text { ponovimo; reč je o } \\
\text { navodnom odgovoru } \\
\text { Paganinija na zahtev } \\
\text { napuljskog kralja da } \\
\text { ponovo odsvira dela koja } \\
\text { nije čuo, jer je kasno } \\
\text { stigao na koncert. }\end{array}$ & $\begin{array}{l}\text { Idiomatski izraz na } \\
\text { srpskom jeziku: } \\
(-) \\
\text { Predlog za prevod: } \\
\text { Kasno Marko na Kosovo } \\
\text { stiže (izraz može da se } \\
\text { koristi samo u slučaju } \\
\text { odbijanja da se nešto } \\
\text { ponovi usled nečijeg } \\
\text { kašnjenja). }\end{array}$ \\
\hline
\end{tabular}




\begin{tabular}{|c|c|c|}
\hline Pettinare le bambole & $\begin{array}{l}\text { „Češljati lutke“; posvetiti } \\
\text { se neproduktivnoj i } \\
\text { detinjastoj aktivnosti. }\end{array}$ & $\begin{array}{l}\text { Idiomatski izraz na } \\
\text { srpskom jeziku: } \\
\text { Trla baba lan da joj prođe } \\
\text { dan. }\end{array}$ \\
\hline Pinco Pallino & $\begin{array}{l}\text { Bilo ko; izmišljeno ime i } \\
\text { prezime koje se dodeljuje } \\
\text { neodređenoj osobi. }\end{array}$ & $\begin{array}{l}\text { Idiomatski izraz na } \\
\text { srpskom jeziku: } \\
\text { (-) } \\
\text { Predlog za prevod: } \\
\text { 1. } \text { Pera Perić. } \\
\text { 2. Osoba x. }\end{array}$ \\
\hline tra Scilla e Cariddi & $\begin{array}{l}\text { Reč je o legendi o dva } \\
\text { čudovišta iz mora u } \\
\text { Mesinskom moreuzu koja } \\
\text { su predstavljala pravu } \\
\text { opasnost za mornare. } \\
\text { Danas se koristi kao izraz } \\
\text { za nekoga ko se nalazi } \\
\text { između dve opasnosti ili } \\
\text { dva izbora podjednako } \\
\text { neprijatna i opasna. }\end{array}$ & 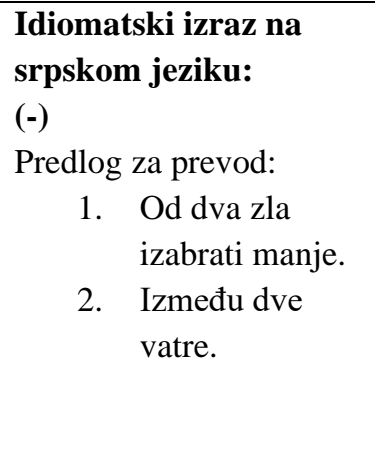 \\
\hline a bocca asciutta & $\begin{array}{l}\text { „Suvih usta“; ostati bez } \\
\text { onoga što smo mislili da } \\
\text { nećemo izgubiti. }\end{array}$ & $\begin{array}{l}\text { Idiomatski izraz na } \\
\text { srpskom jeziku: Praznih } \\
\text { ruku/ praznih šaka. }\end{array}$ \\
\hline ha un diavolo per capello & $\begin{array}{l}\text { „Ima jednog đavola za } \\
\text { svaku vlas kose“; biti } \\
\text { veoma nervozan, }\end{array}$ & $\begin{array}{l}\text { Idiomatski izraz na } \\
\text { srpskom jeziku: Đavo } \\
\text { mu ne da mira. } \\
\end{array}$ \\
\hline andare a gonfie vele & "Ići punim jedrima“ & $\begin{array}{l}\text { Idiomatski izraz na } \\
\text { srpskom jeziku: } \\
\text { 1. Punom parom. } \\
\text { 2.Punim jedrima. }\end{array}$ \\
\hline andare a zonzo & $\begin{array}{l}\text { „Zonzo“; onomatopeja } \\
\text { zvuka insekta. }\end{array}$ & $\begin{array}{l}\text { Idiomatski izraz na } \\
\text { srpskom jeziku: Kao } \\
\text { muva bez glave. }\end{array}$ \\
\hline aria fritta & $\begin{array}{l}\text { „Ispržen vazduh“; nešto } \\
\text { bez smisla i osnove. }\end{array}$ & $\begin{array}{l}\text { Idiomatski izraz na } \\
\text { srpskom jeziku: Luk i } \\
\text { voda. }\end{array}$ \\
\hline $\begin{array}{l}\text { non tutte le ciambelle escono } \\
\text { col buco }\end{array}$ & $\begin{array}{l}\text { „Ne ispadaju sve krofne } \\
\text { sa rupom u sredini“; ne } \\
\text { ispadaju uvek stvari } \\
\text { onako kako bismo želeli. }\end{array}$ & $\begin{array}{l}\text { Idiomatski izraz na } \\
\text { srpskom jeziku: } \\
\text { 1. Ne ide sve po loju. } \\
\text { 2. Nije svaka puška }\end{array}$ \\
\hline
\end{tabular}




\begin{tabular}{|l|l|l|}
\hline & & ubojita. \\
\hline palla al piede & $\begin{array}{l}\text { „Lopta na nozi“; stvar ili } \\
\text { osoba koji sprečavaju } \\
\text { realizaciju nečega. }\end{array}$ & $\begin{array}{l}\text { Idiomatski izraz na } \\
\text { srpskom jeziku: Kamen } \\
\text { spoticanja. }\end{array}$ \\
\hline trovare l'America & $\begin{array}{l}\text { Pronaći nekog ili nešto } \\
\text { apsolutno bolje. }\end{array}$ & $\begin{array}{l}\text { Idiomatski izraz na } \\
\text { srpskom jeziku: } \\
\text { (-) } \\
\text { Neprevodiv element: } \\
\text { Pronaći Ameriku (na } \\
\text { srpskom ima samo jedno } \\
\text { značenje: ne otkriti ništa } \\
\text { novo). }\end{array}$ \\
\hline
\end{tabular}

\subsection{Razlozi ZA POJAVU teškoća u prevodu metafora i idiomatskih izraza}

Da bi idiomatski izraz bio uspešno preveden, on mora biti idiomatski izraz i u kulturi jezika na koji se prevodi. Ekvivalent se ne može formirati onda kada postoji potpuni gubitak elemenata na sintaktisičkom, konotativnom ili semantičkom nivou.

Po Persu, sve naše senzacije su već selektivne interpretacije i sjedinitelji različitih utisaka koji nastaju u trenutku interpretacije (Peirce 2003). Zahvaljujući njemu, znamo da znak ne predstavlja direktnu spoznaju predmeta/reči/objekta, već da bi interpretator mogao da ih razume, oni moraju biti nešto poznato ili pristupačno. Analiza samih signifikanata koji čine ove izraze ovde ne može biti od pomoći. Sledeći problem je taj što su dinamički interpretant, odnosno realan uticaj na um prevodioca ili tumača i logički interpretant (onaj koji je u stanju da zaustavi proces semioze), u ovim primerima međusobno veoma različiti. Treći problem može se takođe povezati za Persovim semiotičkim zapažanjem da znak može imati različite interpretante za različite interpretatore, u zavisnosti od njihovih saznanja ali i istraživanja, bez obzira na sam znak. Svi ovi problemi su evidentni u prevođenju ovakvih izraza.

U prevodu sledeće rečenice na srpski jezik: Il loro matrimonio è finito sugli scogli, nemoguće je upotrebiti metaforu „završiti na grebenu“ $\mathrm{u}$ istom značenju kao „propasti“. U takvim primerima potrebno je pozvati se na opšta znanja ili na kontekst, da bismo odlučili kako da prevedemo figurativnu sliku sa jednog na drugi jezik (primer: „doživeti brodolom“). Sasvim je jasno zašto je problem metafora naročito izražen kod simultanih prevodilaca. Čipoli objašnjava 
da je brzina verbalizacije faktor koji najviše utiče na vernost i izražajnost teksta (Cipolli 1981: 279).

U brojnim slučajevima gde ista metafora u različitim kontekstima može imati i drugačije značenje, ili je pak dvosmislena - interpretativna sposobnost prevodioca će uticati na njegovo shvatanje te dvosmislenosti ili više značenja. Kao da postoji intuitivno očekivanje u razumevanju metafora. Kačari zapaža da izvorni govornici poseduju intuiciju za određivanje doslovnog ili prenesenog značenja kao što znaju da raspoznaju da li je neki govor formalan ili neformalan (Cacciari 1991: 5). U trenucima kada se ne mogu osloniti na kontekst, izvorni govornici intuitivno, ili na osnovu iskustva, razumeju smisao, dok će prevodilac (koji nije izvorni govornik) morati da razmisli:

Onaj ko se služi metaforama izražava se uz pomoć semantičkih kontradiktornosti i upućuje svojim čitaocima poziv da ih razreše. Ako oni to prihvate, i ako pokušaji budu uspešni, ishod je usvajanje pojma koji je, u ekstremno realnom smislu, neizreciv. U tome leži ključna dvosmislenost metafore i njena osnovna snaga: ona izražava normalnim rečima ono što normalne reči same ne bi mogle izraziti, olakšavajući konverziju evidentnih apsurdnosti, u razumljivu istinu ${ }^{4}$ (Basso 1991: 350).

Metafore koje su izvučene iz konteksta najčešće su dvosmislene. Takve metafore nas zapravo stalno navode na izbor, jer u našem tumačenju ne sme ostati nikakva sumnja kako bismo uspeli da ih prevedemo. U tome se krije i sama odgovornost prevodioca, koji mora da odluči, znajući da ambivalentni izraz uvek ima dva ili više značenja. Uzmimo kao primer sledeću rečenicu: Sembra la predica di un professore, gde je ambivalentnost očigledna, jer se akter može samo ponašati poput profesora, sa dominantom ${ }^{5}$ na ,ponašanju“, ili predstavlja kritiku stvarnog profesora, sa dominantom na „kritici“ - ali ne može biti i jedno i drugo. Ovakva ambivalentnost može biti rešena isključivo uz pomoć konteksta jer je jezik sistem (prema Sosirovom strukturalističkom učenju). Zaključujemo da se ambivalentnost metafora može ticati pojma ili sintagme, ne zaboravljajući da

\footnotetext{
4 „Chi produce la metafora si esprime attraverso contraddizioni semantiche ed estende ai suoi ascoltatori l'invito a risolverle. Se questo viene accettato, e se i tentativi hanno successo, il risultato è l'acquisizione di un concetto che è, in un senso estremamente reale, indicibile. Qui sta l'essenziale ambiguità della metafora e anche la sua forza fondamentale: essa ,dice2 con parole normali quello che le parole normali da sole non potrebbero dire, agevolando la conversione di evidenti assurdità in verità comprensibili. “4

5 „Dominanta“ kao jedan od rečeničnih elementa u teoriji prevođenja često se pojavljuje kod Kavanjoli (Cavagnoli 2012).
} 
ambivalentnost može postojati i na nivou rečenice (nisu retki slučajevi gde ambivalentnost postoji kako na nivou pojma tako i na nivou enuncijatuma). Navodimo nekoliko primera:

1) Giovanni, i cui occhi brillavano, ha visto Gianni, suo amico prezioso, mentre attraversava la strada. ${ }^{6}$

Đovani, svetlucavih očiju, video je Đanija, svog dragocenog prijatelja, dok je prelazio ulicu.

Da li su Đovanijeve oči sijale jer je video Đanija, svog dragocenog prijatelja ili iz nekog drugog razloga koji nije iskazan u ovoj rečenici? Metafora „svog dragocenog prijatelja“ znači da je Đani njegov veliki prijatelj, ili je „prijatelj“ zato što je „dragocen“ za Đovanija, iz nekog drugog razloga? Oči koje sijaju na italijanskom jeziku ne moraju nužno da budu pokazatelj sreće, već upravo suprotno: oči „brillano“ i od plača. Na kraju, na nivou enuncijatuma, ko prelazi ulicu, Đovani ili Đani? U ovom primeru, dakle, pronalazimo pojmovnu ambivalentnost metafora: occhi che „brillano"; amico „prezioso“, zatim ambivalentnost na nivou sintagme: Gianni, ,i cui occhi brillavano" ha visto Gianni i semantičku ambivalentnost enuncijatuma: "mentre attraversava la strada. "

2) Mia moglie, un tesoro, sta già aiutando mia nonna con la febbre. ${ }^{7}$

Moja zlatna žena, već pomaže mojoj baki sa temperaturom.

Ovde ćemo razmotriti sledeće faktore: da li je moja žena „zlatna“ jer je spremno pomogla baki, ili je moja žena inače ,zlatna“? Ovde ne pronalazimo pojmovnu ambivalentnost metafore već samo ambivalentnost na nivou sintagme. $\mathrm{Na}$ kraju, pronalazimo i sintaktičku ambivalentnost: ko ima temperaturu? Moja žena ili moja baka?

Interpretirati na ispravan način ovakve delove rečenice, koje samo na prvi pogled nisu od važnosti za prevod, postaje izuzetno zanimljivo, s obzirom na to da ćemo na osnovu našeg prevoda dobiti dva različita značenja: Moja žena je zlato, (jer) već pomaže baki. Ili: Moja žena, koja je zlato, već pomaže baki.

Zanimljivo je u ovom smislu razmotriti i željenu ambivalentnost. Često nalazimo primere u književnosti gde se autor na neki način „,igra“ sa ambivalentnošću i stoga postaje veoma bitno sačuvati takvu ambivalentnost i u

\footnotetext{
${ }^{6}$ Prevod autora rada.

${ }^{7}$ Prevod autora rada.
} 
prevodu. U našem primeru to se može postići na dva načina: Moja žena je zlato, jer već pomaže mojoj baki sa temperaturom. Ili Moja žena je zlato, jer pomaže baki iako ima temperaturu (u drugom primeru moramo „pretpostaviti“ da moja žena, iz nekih drugih razloga, ne može biti pored nekog ko ima temperaturu).

3) Marco, che ha la testa tra le nuvole, sta pensando alla vacanza sulla nave. ${ }^{8}$

Marko, kome je glava u oblacima, razmišlja o odmoru na brodu.

U ovom primeru pronalazimo dve semantičke ambivalentnosti sledećih enuncijatuma: Marko radi na brodu i tamo razmišlja o svom odmoru, ili Marko razmišlja o ideji odmora na nekom brodu. Ili, još: Marko, koji živi u oblacima, već razmišlja o odmoru. Ili, Marko, koji je trenutno u oblacima iz nekih drugih razloga, razmišlja o odmoru. Dobra interpretacija je od ključnog značaja za uspešan prevod ovih rečenica na srpski jezik. Kontekst zasigurno može biti od pomoći, ali ne treba zaboraviti da često (naročito u gramatikama) mi ne prevodimo enuncijatum (gde bismo se mogli osloniti na kontekst), već prevodimo rečenice (fraze), kao u gore pomenutim primerima. U slučaju prevoda rečenica (fraza), najbolje rešenje bi bilo zadržati ambivalentnost i u prevodu: Marko koji je $u$ oblacima, razmišlja o odmoru na brodu. Ono što je važno jeste razumeti da li je u polaznom tekstu ambivalentnost slučajna ili namerna. Namernu ambivalentnost treba sačuvati i u prevodu, ali problem nastaje kada prevodimo slučajnu ambivalentnost metafora. Nije jednostavno zaključiti da li je takva metafora zaista slučajna. Umetnost prevođenja nas uči da osluškujemo i ono što nije izrečeno, napisano, smišljeno, drugim rečima, uči nas da osluškujemo i tišinu teksta (kada autor navodi čitaoca na razmišljanje i zaključke koji često mogu biti različiti za različite čitaoce).

\section{ZAKLJUČAK}

Pokazali smo da je najveći problem prevođenja idiomatskih izraza u samoj metafori koja je i sastavni deo komunikacije. Kačari kaže da se prosečno upotrebljavaju četiri stilske figure na svaki sat govora, a tokom prosečnog života se izgovori 21 milion stilskih figura (Cacciari 1991: 6).

\footnotetext{
${ }^{8}$ Prevod autora rada.
} 
Možda upravo slučaj metafore može da potvrdi razmišljanja Barta kada kaže da je jezik „fašista“, jer mi mislimo da imamo potpunu jezičku slobodu i živimo u ubeđenju da je imamo, a zapravo nije tako (Barthes 2006).

Mogli bismo da se složimo sa stavom koji iznosi Kačari da se svi problemi u prevođenju metafora tiču ne toliko značenja koliko ,upotrebe reči i rečenica od strane govornika“ (Cacciari 1991: 6) i činjenice da se metafora ne može naučiti od drugih, ,ona je više dokaz genijalnosti, jer dobra metafora podrazumeva intuitivnu percepciju sličnosti u različitosti““ (Cacciari 1991: 6).

Poseban problem svakako predstavljaju rečenice koje obuhvataju zastarele metafore, takve koje su nekada bile logične, ali danas to više nisu, a naročito one koje su semantički nepodudarne i koje će verovatno u prevodu izgubiti metaforu. Semioza bi, dakle, tada mogla bila „blokirana“ za jednu grupu tumača, a to će zavisiti i od njihove kulture, kreativnosti, umešnosti ali i enciklopedijskog i etimološkog znanja koje poseduju. Semioza nikada ne može biti zaista blokirana (kao što smo videli u primerima i u našoj analizi). Tamo gde nije postojao idiomatski izraz, poslužili smo se predlogom prevoda koji, iako najčešće bez metafore, uspeva da približno razjasni značenje, mada ne treba zaboraviti da on tada ipak prestaje da bude idiomatski izraz. U malom broju primera nismo našli adekvatni predlog prevoda, što ne znači da on $i$ ne postoji: drugi tumač/autor/interpretator će, zahvaljujući svojim (sa)znanjima, možda uspeti da pronađe odgovarajuće rešenje.

Autor je preko konkretne analize neistraženih idioma i detaljnog opisa umnog procesa pri tumačenju metafora, kojima se svaki prevodilac nužno bavi, želeo da dâ svoj doprinos u borbi protiv „,nevidljivosti“ prevodilaca, iako svestan da je, paradoksalno, njihova nevidljivost zapravo dokaz njihove bravure.

\section{LITERATURA}

Barthes, Roland. 2006. Il senso della moda. Torino: Piccola biblioteca Einaudi.

Basso, H. K. (1991). Le "parole sagge" degli apache occidentali: Metafora e teoria semantica, L'acquisizione, la comprensione, e l'uso del linguaggio figurato: $340-355$

Cacciari, Cristina. 1991. L'acquisizione, la comprensione e l'uso del linguaggio figurato (a cura di). Milano: Raffaello Cortina Editore.

Cavagnoli, Franca. 2012. La voce del testo, l'arte e il mestiere di tradurre. Milano: Giangiacomo Feltrinelli Editore.

Calefato, Patrizia. 2006. Che nome sei?, Roma: Meltemi. 
Cipolli, Carlo. 1981. Meccanismi e processi di memoria nella traduzione simultanea. Processi traduttivi: Teorie ed applicazioni, Atti del seminario su "La traduzione", Brescia: Editrice La Scuola.

Craici, Laura. 2001. Dizionario dei modi di dire. Milano: Vallardi Editore.

De Saussure, Ferdinad. 2009. Corso di linguistica generale. Bari- Roma: Editori Laterza.

Golović, Branko. 2010. Frazeološki srpsko-italijansko-francuski rečnik. Beograd: Albatros plus.

Hjelmslev, Louis. 1980. I fondamenti della teoria del linguaggio (a cura di Giulio C. Lepschy). Torino: Einaudi.

Klajn, Ivan. 2005. Italijansko-srpski rečnik. Beograd: Nolit.

Mounin, Georges. 2006. Teoria e storia della traduzione. Torino: Piccola Biblioteca.

Peirce, Charles Sanders. 2003. Opere. Milano: Bonfantini Bompiani.

Pittano, Giuseppe. 2009. Frase fatta capo ha. Dizionario dei modi di dire, proverbi e locuzioni di italiano. Bologna: Zanichelli.

Ristić, Stojan. 1992. Poslovice naroda sveta. Beograd: Rad.

Schwamenthal, Straniero, M.L. (1999). Dizionario dei proverbi italiani $e$ dialettali. Milano: Rizzoli- BUR.

Stojičić, Đoko. 2006. Srpske narodne izreke. Beograd: Kompanija Novosti. 1.

Šipka, Milan. 2010. Zašto se kaže. Zemun: Prometej.

Traini, Stefano. 2013. Le basi della semiotica. Milano: Bompiani.

Zingarelli, Nicola. 2004. Vocabolario della lingua italiana. Milano: Zanichelli. 
Ana M. Stojanović

\section{INTERLINGUISTIC TRANSLATION OF METAPHORS IN IDIOMATIC EXPRESSIONS FROM ITALIAN TO SERBIAN}

\section{Summary}

Scientists and researchers dealing with the semiotics of translation, agree that the semiosis can never be interrupted and that, therefore, translation is always possible. However, despite their attitudes, the idiomatic expressions or phraseologies that characterize every cultural context, are one of the biggest challenges for both semioticians and translators. All languages in their structure have this kind of "peculiarities". This peculiarity is not only a consequence of rich linguistic practice and centuries-old cultural experience, but is often an indicator of the rich philosophy of life of one nation. The problem is certainly more pronounced with simultaneous and consecutive translators for understandable reasons, so sometimes it is justified to skip the unknown phraseology, bearing in mind that "for a simultaneous interpreter it is important to pass on the message, while for other translators it is important how to pass on the message." In this paper, we will pay attention to idiomatic expressions and their forms of translation from Serbian into Italian, through other phraseologies or equivalents if they exist, and if the expressions do not have an acceptable equivalent, we will offer translation as a possible solution.

In the end, we have paid attention to the ambivalent metaphors and the forms of their correct translation. The goal was certainly to contribute to the work of translators of both languages.

Key words: metaphors, idiomatic expressions, ambivalence, Italian, Serbian 